\title{
Front Matter: Volume 11668
}

, "Front Matter: Volume 11668," Proc. SPIE 11668, High-Power Diode Laser Technology XIX, 1166801 (23 April 2021); doi: 10.1117/12.2596631

SPIE. Event: SPIE LASE, 2021, Online Only 


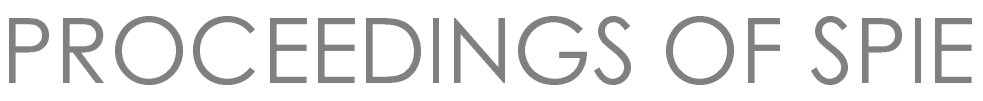

\section{High-Power Diode Laser Technology XIX}

Mark S. Zediker

Editor

6-11 March 2021

Online Only, United States

Sponsored and Published by

SPIE 
The papers in this volume were part of the technical conference cited on the cover and title page. Papers were selected and subject to review by the editors and conference program committee. Some conference presentations may not be available for publication. Additional papers and presentation recordings may be available online in the SPIE Digital Library at SPIEDigitallibrary.org.

The papers reflect the work and thoughts of the authors and are published herein as submitted. The publisher is not responsible for the validity of the information or for any outcomes resulting from reliance thereon.

Please use the following format to cite material from these proceedings:

Author(s), "Title of Paper," in High-Power Diode Laser Technology XIX, edited by Mark S. Zediker, Proc. of SPIE 11668, Seven-digit Article CID Number (DD/MM/YYYY); (DOI URL).

ISSN: 0277-786X

ISSN: 1996-756X (electronic)

ISBN: 9781510641716

ISBN: 9781510641723 (electronic)

Published by

SPIE

P.O. Box 10, Bellingham, Washington 98227-0010 USA

Telephone +1 3606763290 (Pacific Time)

SPIE.org

Copyright @ 2021 Society of Photo-Optical Instrumentation Engineers (SPIE).

Copying of material in this book for internal or personal use, or for the internal or personal use of specific clients, beyond the fair use provisions granted by the U.S. Copyright Law is authorized by SPIE subject to payment of fees. To obtain permission to use and share articles in this volume, visit Copyright Clearance Center at copyright.com. Other copying for republication, resale, advertising or promotion, or any form of systematic or multiple reproduction of any material in this book is prohibited except with permission in writing from the publisher.

Printed in the United States of America by Curran Associates, Inc., under license from SPIE.

Publication of record for individual papers is online in the SPIE Digital Library.

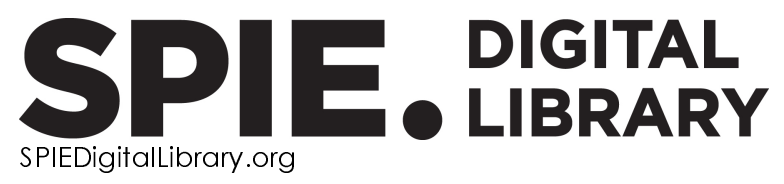

Paper Numbering: A unique citation identifier (CID) number is assigned to each article in the Proceedings of SPIE at the time of publication. Utilization of CIDs allows articles to be fully citable as soon as they are published online, and connects the same identifier to all online and print versions of the publication. SPIE uses a seven-digit CID article numbering system structured as follows:

- The first five digits correspond to the SPIE volume number.

- The last two digits indicate publication order within the volume using a Base 36 numbering system employing both numerals and letters. These two-number sets start with 00, 01, 02, 03, 04, 05, 06, 07, 08, 09, OA, OB ... OZ, followed by 10-1Z, 20-2Z, etc. The CID Number appears on each page of the manuscript. 


\section{Contents}

HIGH BRIGHTNESS LASER DIODES

$1166804 \quad$ High power, high beam quality miniaturized diode laser module for direct material processing around $980 \mathrm{~nm}$ [11668-1]

$1166805 \quad 350$ W high-brightness multi-emitter semiconductor laser module emitting at 976 nm [1 1668-2]

$1166807 \quad$ Epitaxial design progress for high power, efficiency, and brightness in $970 \mathrm{~nm}$ broad area lasers [1 1668-4]

\section{LASER DIODE DEVICE RELIABILITY}

$1166809 \quad$ Broad range pulse widths reliability model for $905 \mathbf{~ n m ~ h i g h ~ p o w e r ~ l a s e r s ~ [ 1 ~ 1 6 6 8 - 6 ] ~}$

11668 OA High-efficiency and reliable pump lasers for fiber lasers [1 $1668-7]$

11668 OB Reliability and degradation mechanisms in high-power broad-area lasers with strained InGaAs-AIGaAs QW and InAs-GaAs QD active regions [1 1668-8]

11668 OC Modeling of the impact of current crowding on catastrophic optical damage in 9xx-nm high power laser diodes [1 1668-9]

\section{WA VELENGTH STABILIZED LASER DIODES}

11668 OE High efficiency $600 \mathrm{~W}, 100 \mu \mathrm{m}$ wavelength stabilized fiber coupled laser diode module for fiber laser pumping [11668-11]

11668 OF Wavelength stabilized fiber coupled modules at 79x nm, 88x nm, and 97x nm with up to 600W output power based on single emitters [1 1668-12]

\section{VISIBLE WAVELENGTH LASER DIODES AND SYSTEMS}

11668 OJ Compact high-brightness and highly manufacturable blue laser modules [1 1668-16]

11668 OK Individually addressable visible laser arrays for display and printing applications [11668-17]

11668 OM Blue laser-assisted kW-class CW NIR fiber laser system for high-quality copper welding [1 1668-19] 
EYESAFE WAVELENGTH DEVICES FOR LIDAR AND SENSING

$1166800 \quad$ High-power high-brightness lasers and amplifiers at 15xx nm [1 1668-21]

$11668 \mathrm{OP} \quad$ Long-range all-solid-state flash LiDAR sensor for autonomous driving [1 1668-22]

11668 OR High-efficiency vertically-emitting chipsets for 3D and proximity sensing [1 1668-24]

POSTER SESSION

$11668 \mathrm{OW} \quad$ Advances in G-stack diode laser using macro-channel water cooling and high thermal conductivity material packaging [11668-29] 